\title{
岡田信一郎の建築作品における梶田恵設計・制作家具の役割 THE ROLE OF KAJITA MEGUMU'S FURNITURE IN OKADA SHINICHIRO'S ARCHITECTURAL INTERIORS
}

\author{
児島 由美子* \\ Yumiko KOJIMA
}

\begin{abstract}
This paper attempts to show the character of interiors designed by the architect Okada Shinichiro based on some pieces made by the furniture maker Kajita Megumu. Although a considerable amount of research about his life, career, work, speeches and writing has been carried out by earlier scholars, little is known about Okada's interior design. On the other hand, research about Kajita has been carried out in connection with a memorial exhibition about him and an exhibition of plans of his furniture and industrial design work. The data collected in the course of this research is very useful in helping us to understand Okada's interior designs. However as research it is inconclusive. In this paper, I collated the plans kept by Okada with the plans kept by Kajita, and thereby established hichot Kajita's works were designed for Okada's architectural interiors. As a result, I was able to clarify the characteristics of Okada's interior design work.
\end{abstract}

\section{Keywords : Okada Shinichiro Kajita Megumu Architecture Interior Decoration Furniture} 岡田信一郎 梶田恵 建築 室内装飾”家具

\section{1.はじめに}

建築家岡田信一郎 (以下、岡田) は自作の重要な作品に梶田恵 (以下、 梶田)の家具・室内デザインを多く採用している。このため、梶田の 家具が岡田作品にとってどのような役割をもっていたかを考察する ことで、岡田の本質が明らかになると考える。

岡田については、彼の人物像、生涯、設計または関係した建築作 品、言論にいたるまで、先学の研究者たちによって多くの研究が行 われてきた。しかし、この中で今回取り上げる梶田について触れた ものはほとんどない状況である注1)。

暒田については家具史の方から『梶田恵回顧展 日本のアール. デコ』(家具の博物館) 注 2) と『梶田恵家具木工芸設計図展』(東京蓺 術大学藝術資料館) 注3) のために調査が行われ、彼が岡田の多くの建 築作品において家具·室内意匠を設計·製作していたことや両人の関 係について明らかになっている。その成果が図録梶田恵回顧展 日 本のアール・デュ』注4)にまとめられており、岡田の建築作品の室内 を知るために大いに役立つ。

これによれば、暒田の仕事の内容は極めて広く、家具デザイナー と工芸作家の両面で優れた作品を残している。その家具作品は様式 主義からモダンまで幅広いが、特にアール・デコについては日本で 最初期に手掛けており、大正 4 年にはフランス政府主催の「装飾美 術と近代工業の国際展覧会」にライティングビューローを出品し、 入賞するほどであった。岡田が梶田を知ったきっかけについては、 梶田が東京美術学校図案科在学中に同校の講師をしていた岡田から 図学か建築装飾の講義受けていた可能性があることと、岡田が雷查 員をしていた大正 11 年の平和博覧会に梶田が出品しており、そのと き岡田の目に留まったのであろうとしている。また、平和博覧会の
翌年、大正 12 年には岡田は䲴山一郎邸の家具を梶田に任せており注 5)、大正 14 年の日赤本社、昭和 2 年の東京府立美術館増築、昭和 5 年の信濃町教会 (戸山教会)などの各建築に梶田の家具を採用したこ とが明らかにされた。このように、既に梶田についての調查研究を 通して、岡田の建築作品との関わりが判明している。

岡田のどの建築作品に暒田の家具が採用されているかという点に ついては一部が明らかにされたものの、具体的に、どのような室内 空間であったか、また、その空間をどのような装飾方法、または考 えによって設計したかという点については明らかになっていないた め、本稿では、以上の点を明らかにするとともに、彼らの設計·製作 活動の背景についても考察を試みたい。

本研究で使用する主な資料は、「梶田恵家具及工芸品設計図」注6). 「岡田信一郎設計建造物家具資料」注 7)所收の家具図、家具配置図と、 「岡田兄弟建築設計図」注 8) 所収の平面図、展開図である。これら を照らし合わせ、岡田が梶田に設計・制作を任せた作品を明らかにす る。さらに、図面の照らし合わせだけでは不十分なものもあるため、 その場合は古写真注 9) ・聞取り資料注 ${ }^{10)}$. 雑誌刊行物注 11 ) 既往研究注 12) を援用する。

\section{2. 調査結果}

使用する図面資料についての調查結果は以下に述べるとおりで ある。

東京藝術大学大学美術館所藏「梶田恵家具及工芸品設計図」は、 梶田が保管していた図面で、家具や照明器具の $1 / 10$ 図、詳細図、配 直図、カーテン掛図、暖炉前飾図、金具図などが収められている。 


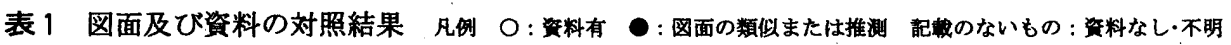

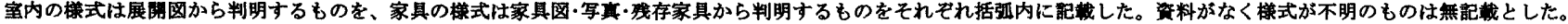
また樣式が判別できるほどの室内の特徽がないものに関しては単に「クラシタク」と紀戴した。

\begin{tabular}{|c|c|c|c|c|c|c|c|c|c|c|c|c|c|}
\hline \multirow{2}{*}{$\frac{1}{\pi 13}$} & \multirow{2}{*}{$\frac{5}{r 13}$} & \multirow{2}{*}{ 稌名 } & \multirow{2}{*}{ 害名 } & \multicolumn{2}{|c|}{ 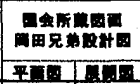 } & EI (J0=7b) & \multicolumn{2}{|c|}{ 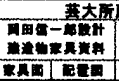 } & \multicolumn{2}{|c|}{ 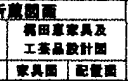 } & $3 x$ & 常 & 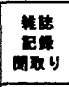 \\
\hline & & & & 0 & 0 & 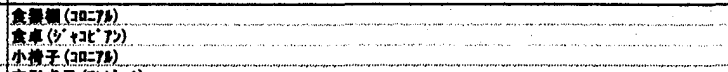 & $\ldots$ & & ona & & & $\begin{array}{l}0 \\
0 \\
0\end{array}$ & \\
\hline \multirow{3}{*}{714.12} & \multirow{3}{*}{$\pi 15$} & \multirow{3}{*}{ 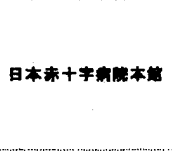 } & \multirow{3}{*}{$(\ln 2)$} & \multirow{3}{*}{0} & \multirow{3}{*}{0} & 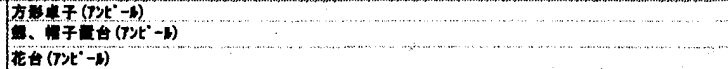 & 0 & & & $\begin{array}{ll}0 \\
0 \\
0\end{array}$ & & & \\
\hline & & & & & & 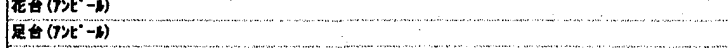 & 0 & & & $\begin{array}{l}0 \\
0\end{array}$ & & & . \\
\hline & & & & & & 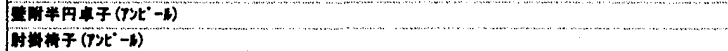 & 0 & & ....... & 0 & & & 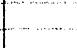 \\
\hline 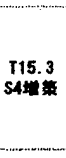 & s2 & 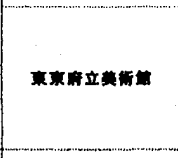 & (2) & 0 & 0 & 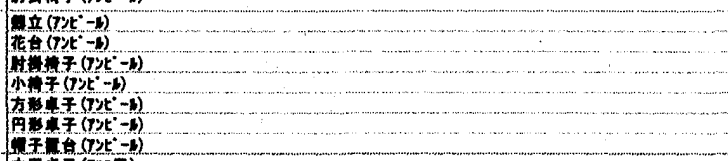 & $\begin{array}{l}0 \\
0 \\
0 \\
0 \\
0 \\
0 \\
0 \\
0\end{array}$ & . & $\begin{array}{l}0 \\
0 \\
0\end{array}$ & $\begin{array}{l}0 \\
0 \\
0 \\
0 \\
0 \\
0 \\
0 \\
0\end{array}$ & $\begin{array}{l}0 \\
0 \\
0 \\
0 \\
0\end{array}$ & & ......... \\
\hline Tis.3 & \multirow[t]{3}{*}{$\Gamma 14$} & 类十キ木杜 & non & 0 & & 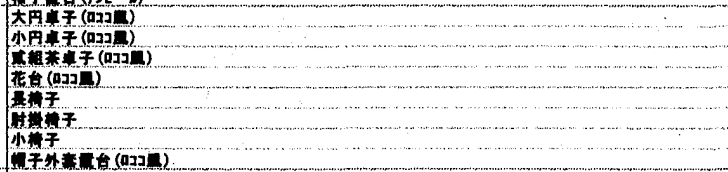 & $\begin{array}{l}0 \\
0 \\
0 \\
0 \\
0\end{array}$ & .... & $\cdots$ & $\begin{array}{l}0 \\
0 \\
0 \\
0 \\
0 \\
0 \\
0 \\
0 \\
0 \\
0\end{array}$ & ..... & $\cdots$ & $\cdots$ \\
\hline \multirow[b]{2}{*}{ s3 } & & \multirow[b]{2}{*}{ ate } & 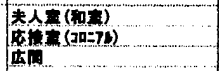 & $\begin{array}{l}0 \\
0 \\
0\end{array}$ & 0 & 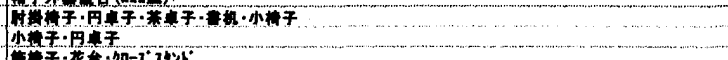 & & & & $\begin{array}{l}0 \\
0 \\
0\end{array}$ & & & \\
\hline & & & 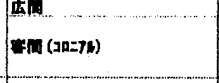 & - & $\circ$ & 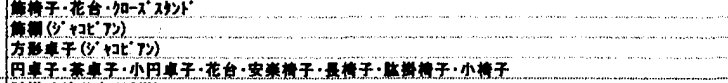 & $\ldots$ & $\cdots$ & 2019 & $\begin{array}{l}0 \\
0 \\
0 \\
0 \\
0\end{array}$ & & & \\
\hline se & sa & 日末大夙支音 & Ane & & & 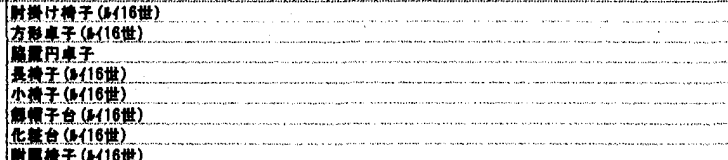 & $\cdots$ & -1 & $\begin{array}{l}0 \\
0 \\
0 \\
0 \\
0 \\
0\end{array}$ & $\begin{array}{l}0 \\
0 \\
0 \\
0 \\
0 \\
0\end{array}$ & & $\cdots$ & $-\cdots$ \\
\hline 55.9 & s5 & 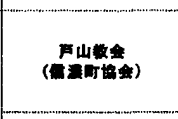 & 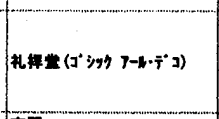 & $\circ$ & 0 & 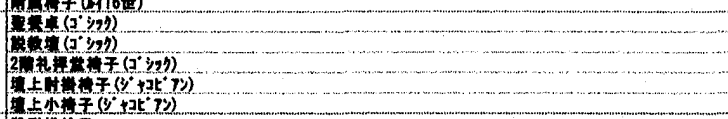 & $\begin{array}{l}0 \\
0 \\
0 \\
0\end{array}$ & (n)....... & $\begin{array}{l}0 \\
0 \\
0\end{array}$ & 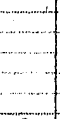 & $\begin{array}{l}0 \\
0 \\
0 \\
0 \\
0 \\
0\end{array}$ & 0 & $5 \cdots \cdots$ \\
\hline S71Rett & sB & 山سE & 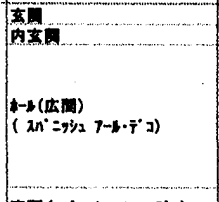 & 0 & 0 & 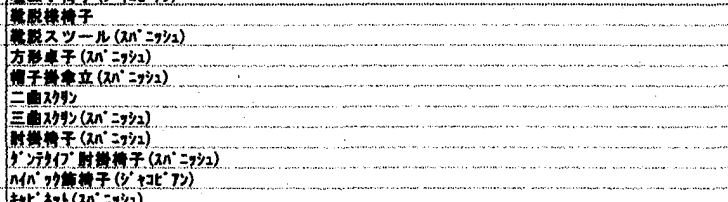 & $\mid \begin{array}{c}0 \\
0 \\
0 \\
0 \\
0 \\
0 \\
022\end{array}$ & $\begin{array}{l}0 \\
0 \\
0 \\
0 \\
0 \\
0 \\
0 \\
0 \\
0 \\
0\end{array}$ & \begin{tabular}{|c|}
0 \\
0 \\
0 \\
0 \\
0 \\
02 \\
0
\end{tabular} & $\begin{array}{l}0 \\
0 \\
0 \\
0 \\
0 \\
0 \\
0 \\
0 \\
0\end{array}$ & $\begin{array}{l}0 \\
0\end{array}$ & 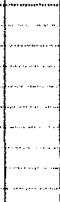 & $(-\cdots \cdots$ \\
\hline & & & $\ln \left(2 x^{\circ}=y^{\prime} / 21-7-k \cdot F^{\prime} J\right)$ & $\circ$ & 0 & 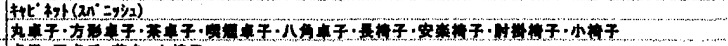 & $\cdots$ & $\cdots$ & on & $\circ$ & $\cdots$ & wa... & $x_{0}$ \\
\hline & & & 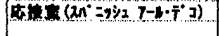 & 0 & 0 & 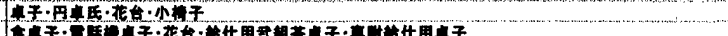 & & 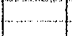 & & 0. & & 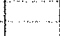 & $\cdots$ \\
\hline & & & AN $\left(x n^{n}=9 \% 1\right)$ & $\circ$ & $\circ$ & 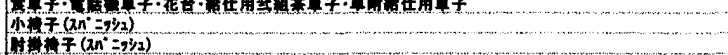 & 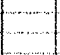 & $+\cdots$ & ant & $\begin{array}{l}\frac{0}{0} \\
0\end{array}$ & : & & \\
\hline & & & 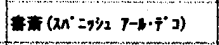 & $\circ$ & 0 & 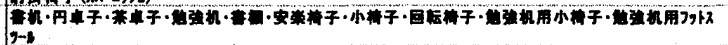 & & & & 0 & & & \\
\hline & & & 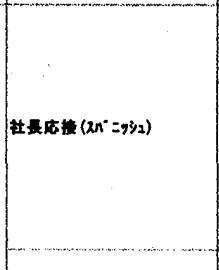 & 0 & 0 & 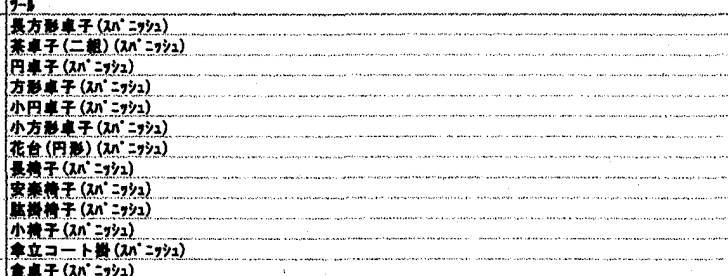 & $-\cdots$ & + & $\begin{array}{l}0 \\
0 \\
0 \\
0 \\
0 \\
0\end{array}$ & 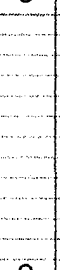 & $\begin{array}{l}0 \\
0 \\
0 \\
0 \\
0 \\
0 \\
0 \\
0 \\
0 \\
0 \\
0 \\
0 \\
0\end{array}$ & 0 & 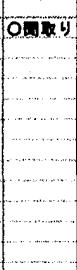 \\
\hline & & & $E *(1+4 ; x)$ & 0 & $\circ$ & 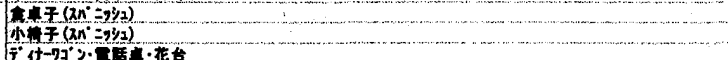 & $-\cdots$ & & 0 & $\begin{array}{l}0 \\
0 \\
0\end{array}$ & 0 & $\cdots$ & $\cdots$ \\
\hline & & & & & & 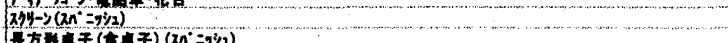 & -1 & $\cdots$ & 은 & 0 & 0 & 0 & \\
\hline s9 & s9 & 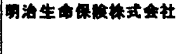 & 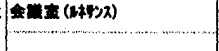 & 0 & $\circ$ & 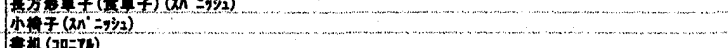 & 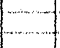 & $\cdots$ & $\begin{array}{l}0 \\
0 \\
0\end{array}$ & 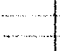 & $\begin{array}{ll}0 \\
0 \\
0\end{array}$ & 0 & \\
\hline & & & & & & 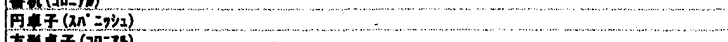 & . & & 0. & & & & \\
\hline & & & 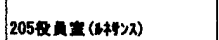 & 0 & 0 & 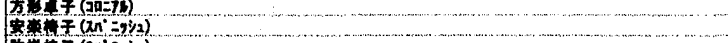 & $\ldots \ldots$ & $\cdots \cdots \cdots \cdot \cdot$ & $\begin{array}{l}0 \\
0 \\
0\end{array}$ & & 0 & 0 & $\ldots \ldots \ldots$ \\
\hline & & & & & & 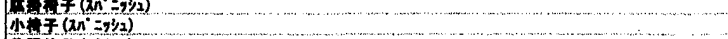 & & & 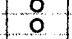 & $\ldots$ & $\begin{array}{ll}0 \\
0 \\
0\end{array}$ & & \\
\hline & & & & & & 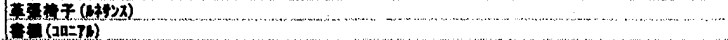 & & & 0 & & 0 & 0 & \\
\hline & & & 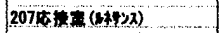 & o & o. & 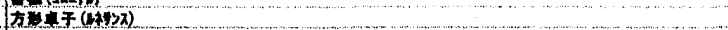 & 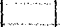 & & 0 & & 0 & & \\
\hline & & & & & & 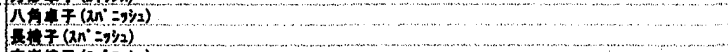 & 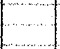 & & 0 & & $\begin{array}{ll}0 \\
0 \\
0\end{array}$ & & \\
\hline & & & 208B & $\circ$ & 0 & 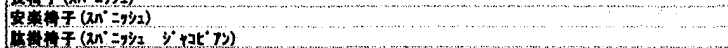 & & & 0 & & 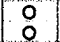 & & \\
\hline & & & & & & 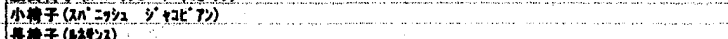 & $\ldots \ldots$ & m & 0 & & 0 & & \\
\hline & & & 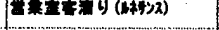 & Oxhe & & 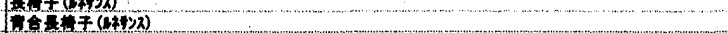 & & & & & 0 & 0 & \\
\hline 不田 & sion & 4 \# & Din $(2 n=9 / 2)$ & 0 & 0 & & & & onest & & & & ONDE: \\
\hline & & & 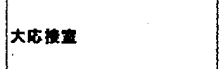 & & & 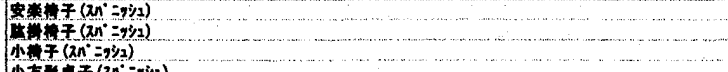 & $\begin{array}{l}0 \\
0 \\
0\end{array}$ & $\begin{array}{l}0 \\
0 \\
0\end{array}$ & & & & & \\
\hline 不用 & 不用 & 中撸 & 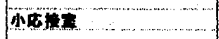 & -1 & & 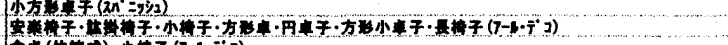 & 0 & $\therefore$ & & & & & \\
\hline & & & 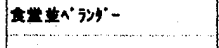 & & & 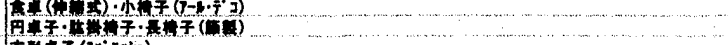 & 0 & 0 & & & & & \\
\hline & & & 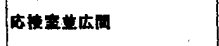 & & & 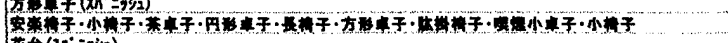 & 0 & 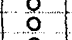 & & & $\ldots . .$. & & \\
\hline 不闻 & 平 & F用 & X & 0 & 0 & & 0 & & & & & & Ond \\
\hline & & & $\tan ($ & 0 & & & & & Q and & 0 & & & \\
\hline 不用 & 不用 & 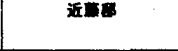 & 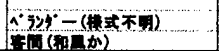 & 잉 & 0 & 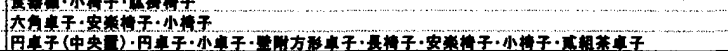 & & & & 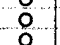 & & & \\
\hline
\end{tabular}


美濃紙にインキングし、彩色したもので、寸法線が点線、寸法が アラビア数字で書かれており、単位は寸である。図面名は記載され ているが、室名や建物名が記載されている図面が少ないため、他の 資料を援用しなければ各図面について、どの建築作品のものである か特定することは難しい。同美術館所藏「岡田信一郎設計建造物家 具資料」は、岡田が保管していた建筑設計図の一部である主 ${ }^{13)}$ 。卜 レーシングペーパーや美濃紙に、鉛筆で描かれており、彩色されて いるものもある。青写真の図面もある。建物別に図面が分類された 状態で保管されており、家具図、配置図、カーテン掛図、スケッチ が収められている。寸法線は点線と実線があり、寸法はアラビア数 字、単位は寸である。図面名や縮尺、室名、建物名が記載されてい るものがあったり、岡田の印が押されているものがあったりと様々 である。青写真の図面は、「梶田恵家具及工芸品設計図」の書式によ く似ていることから、梶田が描いた図面である可能性が高く、青写 真の図面以外でも寸法線が点線のものは、書式や図の様子が「梶田 恵家具及工芸品設計図」に類似しているので、暒田の図面である可 能性が高い。また、寸法線が実線で書式も異なるが、「梶田恵家具及 工芸品設計図」に収められた図に類似した形状の家具が描かれてい る図面があることから、岡田がイメージしている家具を描いた上で 暒田に設計を依頼していたのではないかと推察できる。

しかし、いずれも裹付けがなく、さらなる調查が必要である。

\section{3. 考察}

\section{3-1. 梶田が関わった岡田の建築作品と室の種類}

図面の書式や図面にある家具の種類、資料のなどの分析から判断 して、岡田の建築作品における家具の殆どは暒田が設計した可能性 が高いと考えられる。しかし、ここでは、図面やその他の資料から 確認できたものだけを取り上げ、梶田が関わった岡田の建築作品と して表 1 にまとめた。以下にその 13 例を竣工年順にあげる。

鳵山的（大正 13 年） 日本赤十字病院本館（大正 14 年 12 月）東京 府美術館（大正 15 年 3 月） 日本赤十字本社（大正 5 年 3 月修繥）塚 越邸(昭和 3 年) $\quad$ 日赤大阪支部 (昭和 4 年) 戸山教会 (昭和 5 年 9 月) 注 14) 山尾邸 (昭和 8 年頃) 注 15) 明治生命保険会社 (昭和 9 年) 今井邸 (昭和 10 年頃) 注 16) 中野邸(竣工年不明) 守田邸(竣工年不 明) 近藤邸 (拨工年不明)

以上より、暒田が関わった岡田の建築作品は、住宅建築が 7 例と 一番多く、次いで病院も含めると公共建筑が 5 例、商業建築が 1 例 であることがわかる。

次に、これらの建築において梶田が担当したのはどの部分であっ たかをみると、応接間、応接間兼広間が 10 例と最も多く、次いで食 堂が 6 例、貴賓室、客間がともに 3 例、便殿、広間・ホール、ベラン ダーがともに 2 例、そのほか、礼扯堂(一部)、会議室、役員室、書 斎、支那室、玄関、内玄関、店頭、夫人室、着換室がともに 1 例で あることがわかる。部屋の用途を考え合わせると、梶田が岡田の建 築作品のために設計·製作した家具の多くは、私的な用途の部屋より、 客人を通すような公的な用途の部屋に採用されたことがわかる。こ れは建築の規模に関わらず共通している。

以上から、梶田は住宅のような小規模の建築に携わることが多く、 担当する部屋は、応接間や食堂など公的な用途の部屋が多いという 傾向が見られる。
ただし梶田の場合、設計して自身の工房で製作まで行う場合と、 設計だけをして製作はほかの工場に出す場合があったので、後者な ら建築全体の家具・室内意匠の設計もしていることもある。

これには小規模な仕事しか請けられない暒田工房の製作体制が背 景にあったと考えられる。当時の梶田工房には 4 名のスタッフがお り、製作スタッフは彫刻象嵌の 1 名であった。加えて、梶田工房で は一工程毎に箃しいチェックを行うため、工期と人工がかさんで高 価になった注 18)。このような状況であるため、受注も小規模のもの しか受けられないし、発注側も予算や工期に余裕がない限りは規模 の大きい仕事を頼めなかったと考えられる。実際に、梶田が担当す るのは建築規模に関わらず、いくつかの特別な部屋だけであること が多い。今回の調査結果では図面資料から裏付けができたものしか 取り上げていないので確かではないが、表 1 に示した 13 例の建築作 品について言えば、すべてに当てはまる。

たとえば、昭和 9 年に竣工し、岡田の遺作といわれている明治生 命保険会社の設計については、1 階店頭、2 階各室の家具やカーテン など大部分を行っているが、2 階社長応接室の家具だけを梶田工房 で製作し、残りは寺尾商店に製作を外注している。そして講堂の連 結椅子などはコトブキ商店に外注している。

しかし、このような製作体制だったからこそ非常に工芸的で緻密 な家具を製作することができたのである。逆に、工芸的で緻密な家 具を製作するためにこのような製作体制にしていたといったほうが 適切かもしれない。それだからこそ、岡田は自身の建築の顔であり、 客人の目に触れる公的な用途の部屋(接客空間)を梶田に担当させた と考えられる。

\section{3-2. 暒田が担当した室の室内装飾}

次に、「岡田信一郎設計建造物家具資料」の展開図から梶田が担当 した室の室内装飾様式をみると、表 1 に示したように、ゴシック、 ルネサンス、ロココ、ジャコビアン、スパニッシュ、コロニアル、 アンピールといった古典様式から中国風、アール・デコまで自在に扱 っていたことがわかる。多いのはやはり古典様式だが室内装飾様式 と家具の様式が対応していて、様式の鬼才といわれた岡田にとって、 家具についてもあらゆる様式をこなせる梶田はこの上ないパートナ 一だったと考えられる。しかも、その水準はデザイン的にも工作的 にも極めて高いのである。

明治生命保険株式会社の社長応接室はスパニッシュ様式の室内に 同様式の家具を配置している。スパニッシュ様式は本来、粗野でダ イナミックな意厈が特徴であるが、これとは逆に梶田の家具は細か な象嵌や彫刻を施した美術工芸的ともいうべきものである。しかし このことにより室内をより高雅な雰囲気にしているのである。洋風 の室内は全体の完成度が家具によって非常に大きく左右されるとい うことを、岡田は当然ながら熟知していたであろらから、このよう な梶田の家具を自身の建築作品に数多く採用した点に岡田の様式建 築に対する姿勢を見ることができる。数奇屋建築をつくるような細 やかで精緻な感覚で様式を扱い、細部のディティールにまで配虑し た室内を最後に仕上げる家具としては、同じく細部まで䌁密に仕上 げられた美術工芸品のような梶田の家具でなければならなかった。 すなわち、これが岡田信一郎の建築作品における梶田の家具の役割 の一つといえる。 
また、一方で異なる様式を同じ室内に用いている場合がある。た とえば、鳩山邸の第 3 応接室(食堂)では、ジャコビアン様式の室内 に同様式の食卓とコロニアル様式の椅子と食器棚を配置している。 様式は異なるが、いずれもルネサンス期に興った様式であるため細 部の形態や彫刻が違っていても、比較的近似したデザインで、調和 しやすい。むしろ、ジャコビアン調に忠実にするとやや重苦しい印 象になり、コロニアル調に忠実にするとやや軽すぎる印象になるた め、併せて用いることによって、バランスのとれた室内装飾を実現 させていると考えられる。このような視点に立って、表 1 を改めて みると、鳩山邱の第 3 忘接室のようにその室内装飾様式が興った時 代と同時代の様式を組み合わせているパターンと、古典様式にモダ ンを加味してアレンジしているパターンがあることに気づく。

このように、室内装飾の加減を行う要素としての役割も岡田の建 築作品における梶田の家具の役割であったと考えられる。これは、 岡田同様に様式を自在に扱らことができた暒田だからこそできた仕 事であった。
また、多くの様式の中でもゴシック期とルネサンス期の装飾を用 いたものが多いが、「元来兄は西洋史については『ゴシック』時代と 『ルネサンス』時代が好きであった。徙って『ルネサンス』形式に よる作品がまことに多い一以下略」注 19) と、弟の岡田捷五郎が雑誌 記事に書いていることからも分かるように、これは室内装飾の設計 というような細かい点まで配慮が必要な作業には、設計者の性格や 趣向がより顕著に表れることを裏付けている。

\section{3-3. 関わっていた期間}

表 2 より、梶田が岡田作品に関わった期間は、今回の調査で判明 したものだけで見ると、大正 13 年の鳩山邸設計段階から数えて一昭 和 7 年に岡田は亡くなるが一昭和 10 年頃に完成した今井邸までの約 12 年間である。この 12 年間は、ちょうど岡田が建築の設計活動に 復帰してから盛んに設計活動を行っていた時期である。大正 11 年の 大阪高島屋から亡くなるまでの間に 198 件もの設計を手がけたが、 梶田と仕事をした期間はまさにこのときであった。また、梶田にと

表 2 岡田信一郎と梶田恵の年譜・作品 (次頁に続く)

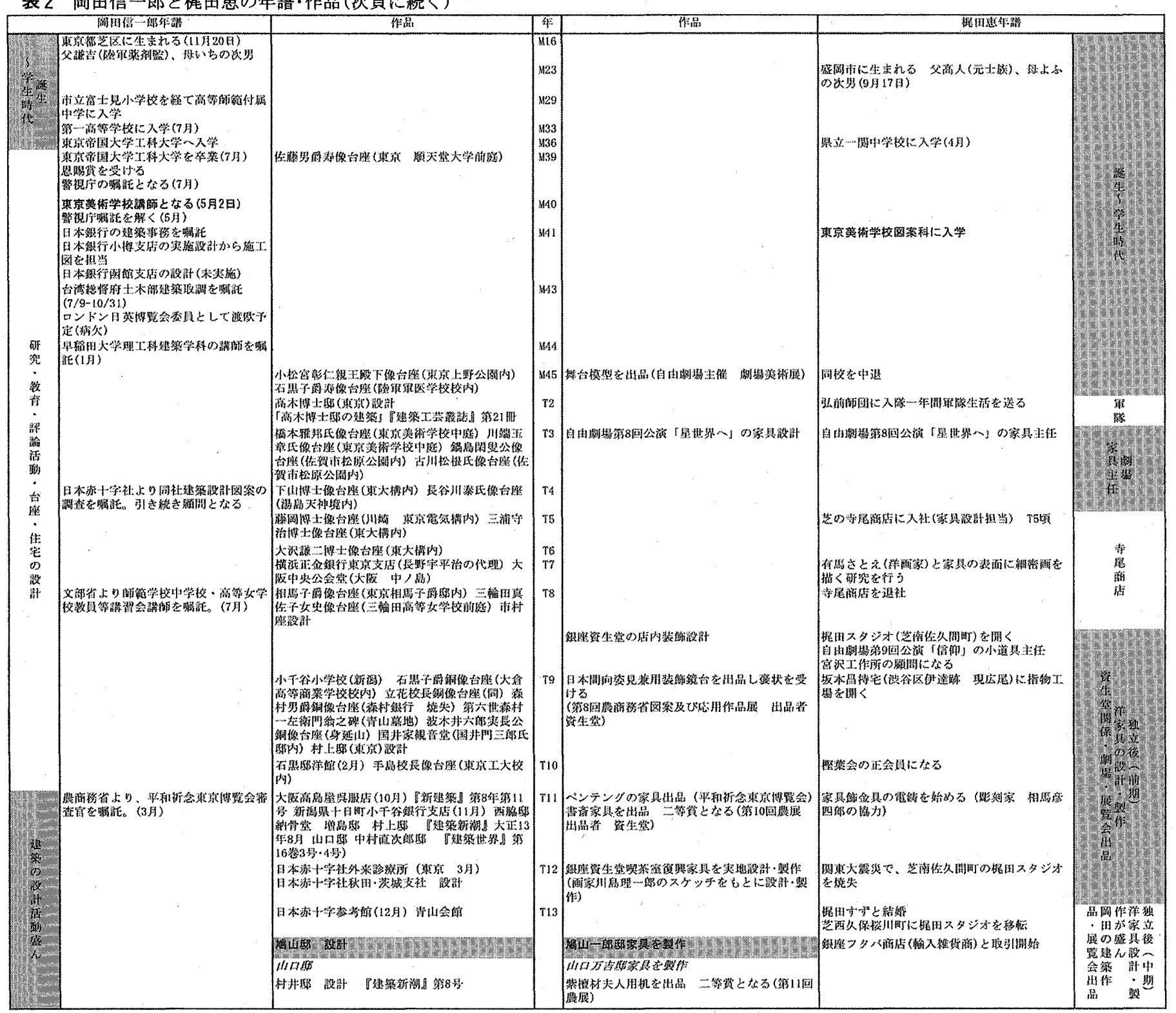

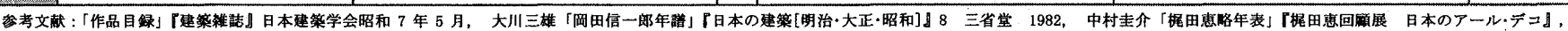
財団法人家具の博物馆盘集·発行, 1980 年 11 月 11 日 
ってもこの 12 年間は最も洋家具を製作した時期で、梶田工房の最盛 期であった。岡田の建築作品のための製作活動のほか、ほぼ毎年の ように商工展や帝展に出品し受賞している。梶田は、大正 8 年に寺 尾商店を退社して、梶田スタジオを開いた後、関東大震災までの期 間は、自由劇場第 9 回公演「信仰」の小道具主任や、宮沢製作所の 顧問などを務め、主に資生堂関保の仕事をしていた。岡田と仕事を するようになったのはちょうど関東大震災後で、今回の調査で判明 した建築作品の家具はすべてこの時期に設計·製作された。

これらの背景には、大正から昭和初期にかけての好景気と、関東 大震災による建築需要の高まりが大きく影響していると考えられる。 表 2 からも分かるように、岡田が亡くなって、建築関係の仕事が少 なくなってからと、価格統制令が布かれた昭和 14 年以降、暒田の作 品に占める工芸品の割合が増えた。また、統制下でも材料を供給し てもらうようにと木工芸作家の地位向上のための活動も盛んに行っ ていたことからも、高級な洋家具を作るための材料がそしくなって いた様子が伺え、岡田の建築作品のために質の高い家具が製作でき
たのは当時の社会背景の影響が大きかったといえる。

4. まとめ

芸大所蔵の「梶田恵家具及工芸品設計図」の中から、梶田が岡田 の建築作品のために設計·製作したものを特定し、その結果について 考察を行った。

岡田の建築作品において梶田が担当した部分についての考察では、 梶田が住宅のような小規模の建築に携わることが多いこと、応接間 や食堂などの公的な用途の部屋の家具·室内装飾を担当することが 多かったことを明らかにした。その要因として、梶田の設計·製作の 方法を取り上げ、自身の工房で一貫して行う方法と設計を行って、 製作は外注する方法があることを明らかにした。また、暒田工房の 小規模な製作体制によって非常に美術工芸的で質の高い洋家具を製 作できたことに注目し、そのような質の高い家具だったからこそ、 岡田は自身の建築作品にとって顔とも言うべき客を通す室内空間に それらの多くを採用したと考えた。

つぎに、暒田が担当した室の室内装飾について分析と梶田による

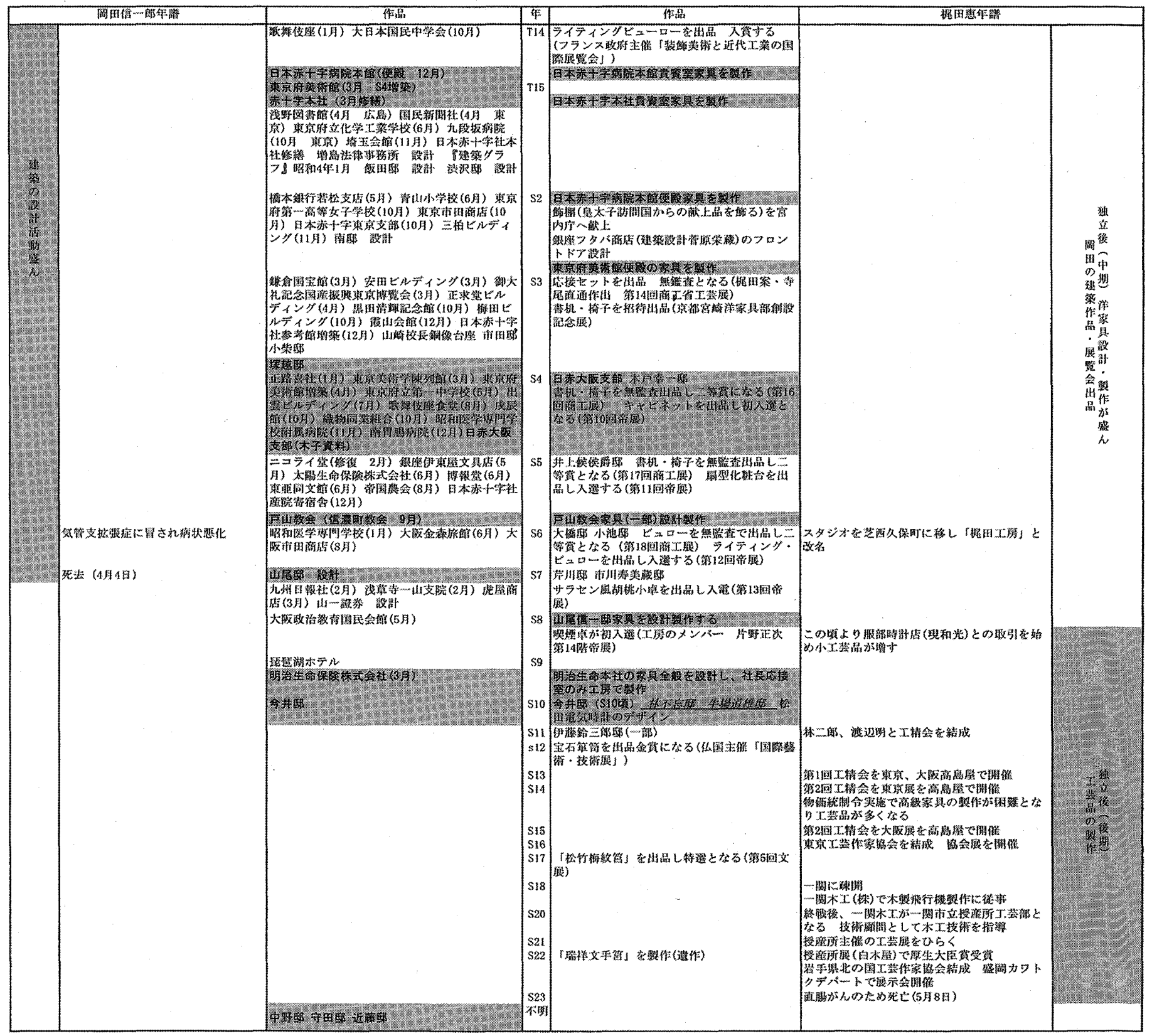


家具の役割について考察では、細やかな点にまで配虑し日本建築の ような感覚で幅広い様式を扱っていた岡田にとって、同様に様式を 自在に扱う梶田はパートナーのような存在であった。また、その美 術工芸的な家具は岡田の建築作品を仕上げる役割を持っており、岡 田がこれによって自身の理想する細やかで整然とした室内を実現さ せようとしたと考えた。

さらに、岡田は古典様式に忠実に設計をしただけではなく、同時 代に興った様式の特徴を熟知し、それらを組み合わせて設計してい たことに注目し、梶田の家具は室内装飾の加堿を行うためのディテ イールとしての役割も担っていたと考えた。これは「過去の建築様 式のディティールは新建築意匠の材料」注20) とした岡田の設計姿勢 をよく表している。

家具·室内装飾は、室内空間の完成度や雾囲気に非常に大きく影響 することから、細やかな点にまで配虑が必要とされる。したがって、 以上のように、家具·室内装飾を分析したことで、岡田の設計意図や 趣向といった本質的な姿勢をうかがい知ることが出来たと考える。

最後に、梶田が岡田の建築作品に関わっていた期間についての考 察を行った結果、両人とも設計活動を最も盛んに行っていた時期で あったことがわかった。岡田はそれまで蓄積した古典様式の知識を 取り入れた建築を数多く設計し、梶田は自身の工房を開き、質の高 い高級家具を設計・製作し、数々の展筧会で受賞していた時期であっ たことが分かった。また、そらした活動が可能となった背景には震 災後の建築需要の高まりから昭和初期にかけての好景気という社会 状況が非常に大きく影響していた。そのため、その後の社会状況の 悪化や岡田の死によってこうした作品が生まれることはなくなった。 そういった意味でもここで取り上げた岡田と梶田による作品は非常 に貴重なものであるといえる。

今回の調查では、岡田や梶田が保存していた図面の多くが震災や 戦禍を奇跡的に逃れて残っていたおかげでこのような結果を得るこ とができた。しかし、梶田の図面のほとんどには物件名、室名が記 載されていないため、図面を検討するための手がかりがそしく、今 回使った資料だけでは不十分であった。そのため、まだ多くの図面 がどの建筑作品のものであるか特定できていない。今後、新たな資 料によってさらに研究が進展することを望む。

謝辞

本研究にあたり、多くの方々にご協力とご指導を賜りました。 ここに記して感謝の意を表します。ありがとうございました。 京都女子大学家政学部生活造形学科 小泉和子教授 千葉大学工学部 モリス・マーティン助教授 東京藝術大学大学美術館 島津京助手 芸術資料係 高柳智氏 明治安田生命相互保険会社 秋元俊一氏 株式会社メック・デザイン・インターナショナル 徳田裕二氏 (株) 竹中工務店 東京本店 樋口成康氏 株式会社 文化財工学研究所 石川秀樹氏 信濃町教会＼cjkstart福田啓三氏

注

注 1) 拙稿「岡田信一郎設計建策の家具·室内装飾と梶田恵 明治生命館の 家具を例に」『日本建築学会大会学術講演梗概集』2006 年 F-2 分冊 p. 515 において、岡田の建勧作品の一つである重要文化財明治生命館の 室内に用いられた暒田の家具を明らかにすることで、ルネサンス風の外 観が印象的な明治生命館の内部空間はどのようなものであったかを考察 した。

注 2）「暒田恵回顧展 日本のアール・デコ」(家具の博物館) 昭和 55 年 11 月 図録『梶田恵回顧展 日本のアール・デコ』, 財団法人家具の博物館編 集·発行, 1980 年 11 月 11 日 目次は次のとおりである。「楃田恵回俩展 開催にあたって」小泉和子, 「棍田恵の作品と生涯」中村圭介,「ア
ール・デコの世界」键和田務,「梶田恵と岡田信一郎」前野まさる, 「梶田恵の思い出」森口多里,「梶田恵略年表」中村圭介，「梶田恵 展出品目録」

注 3）「梶田恵家具木工芸設計図展」（東京藝術大学勢術資料館）1981 年 6 月 29 日(月) 7 月 11 日（土） 図録『昭和 55 年新収藏作品 梶田恵家具木 工芸設計図展』奥付なし 目次は次のとおりである。「梶田恵と家具」 前野まさる，「特別出品目録」

注 4）前揚 注 2) 「暒田恵の作品と生涯」中村圭介,

注 5）東京勢術大学大学美術館所蔵「梶田恵家具及工芸品設計図」に、この ときの出品作品の設計図が収められている。高島屋平和博陳列場家具と して、ヘップル杖仆様式の直線的な形に花輸の模様を施したスリーボールドスリリー ン、スツール、テーブルを出品していた。

注 6) 東京勢術大学大学美術館所藏「梶田恵家具及工芸品設計図」1569 枚 碓 皮紙・美濐紙・インキング・彩色, 梶田恵の家具設計図・家具配㯰図・I 芸作品の姿図・詳細図を所収

注 7）東京藝術大学大学美術館所藏「岡田信一郎設計建造物家具翼料」 1014 枚 紙、淡彩，岡田信一郎の建築作品の家具設計図・家具配置図・カー テン図を所収

注 8）国立国会図書館菥蔵「岡田兄弟建築設計図」349 件 9,859 枚 岡田信 一郎、岡田捷五郎兄弟の建築作品の設計原図を所収

注 9）『琵田恵回顧展 日本のアール・デコ』(家具の博物館)のための調査の 際に、桙田の関係者から提供を受けた梶田作品の写真の複写 小泉和子 生活史研究所所藏

注 10）前揚 注 9）と同時に行った関係者への聞取り調查から得られた情報 を整理したもの 東京勢術大学大学美術館所藏

注 11）岡田の建築作品を紹介する雑誌等、定期刊行物

注 12）前場 注 2）「梶田恵の作品と生涯」中村圭介及び、前野堯「様式美 の婏歌一用と美の迫間で-」， 大川三雄「岡田信一郎年譜」『日本の建築 明治大正昭和』， 8, p. 114-130，三省堂，1982.8

小林文子 大川三雄「岡田信一郎（1883～1932）の住宅作品にみる特徴 について 〜国立国会図畫館所蔵の設計図書を中心とする考察〜」『日 本建築学会大会学術講演梗概集』F-2 分冊, p. 369 1999. 9

注 13) 株式会社 文化財工学研究所 石川秀樹氏のご教示によると、もとは 岡田が保管して、その死後に家族から国立国会図書館へ寄贈された図面 だったという。現在、国立国会図書館が所藏している「岡田兄弟建築設 計図」をみると、家具やその配㯰図といった図面がほとんど見当たらな いのは、ここから分けられた家具や配置図といった図面が東京藝術大学 大学美術館に移管されたからである。

注 14）日赤大阪支部の設計を実際に行ったのは木子七郎(日赤技師)である が、日本赤十字社の建築碩問であった岡田のもとで暒田が家具を設計·製 作を担当した背景にはすくなからず岡田の影響はあったと考え、本稿で は岡田の建築作品のひとつとして扱うことにする。

注 15）山尾邸の竣工年については明らかになっていないが、前揚 注 12） 大川三雄「岡田信一郎年䪭」において、昭和 7 年に設計とあることや、 前揚 注 2）中村圭介「梶田恵略年表」より、家具の設計製作が昭和 8 年であることから、䇋工年を昭和 8 年頃と推定した。

注 16）聞取り資料より、今井邸の家具の納入が昭和 10 年頃であることから、 竣工年を昭和 10 年頃と推测した。

注 18）前揚 注 2）「梶田恵の作品と生涯」中村圭介

注 19）岡田捷五郎「岡田信一郎（兄を語る）」『建築界』vol. 14 no. 12 p19-24 理工図書株式会社編·発行

注 20）岡田信一郎「新建築の意義」『建築雑誌』第 28 集 331 号 日本建築学 会 1914 年 